\title{
Changes in Activities of Inorganic Carbon and Ammonium Uptake by Phytoplankton from May to August, and Their Relation to Water Temperature in Lake Nakanuma, Japan
}

\author{
Tatsuo Miyazaki, Masanori Watase and Kazuyoshi Miyake
}

\begin{abstract}
Daily and weekly sampling was carried out from May to August in 1986 in Lake Nakanuma to estimate the effects of environmental factors on the uptake of inorganic carbon and ammonium by phytoplankton. Rates of uptake of carbon and ammonium, on the whole, increased during the sampling period, though daily and weekly changes occurred. Water temperature among environmental factors examined affected most the uptake activities. Light and nutrients exerted only minor effects on the increases in the uptake activities. The changes in these activities did not correspond to those of chlorophyll $a$ concentration. Active uptake did not necessarily increase phytoplankton biomass.
\end{abstract}

Key words : carbon uptake, ammonium uptake, water temperature, phytoplankton

\section{Introduction}

Uptake of carbon and nitrogen by phytoplankton in lakes in temperate regions is usually higher in summer, compared with the other seasons (Yamaguchi and Ichimura, 1972 ; Watanabe, 1980 ; Robarts, 1984 ; Miyazaki, et al., 1985b ; SeIKe et al., 1986). Higher solar radiation, higher water temperature and nutrient conditions may cause the higher activities in summer (ARUGA, 1965 ; KIRK, 1986). However, it has been difficult to estimate which environmental factors affect most the seasonal changes in uptake, because sampling intervals in most studies have been too long to infer any relationship.

Phytoplankton biomass and activities may change daily (Côté and Platt, 1983 ; Falkowski, 1984 ; Tilzer, 1984). If so, measurements at such intervals as once or twice a month may be insufficient to obtain typical activity levels in a sampling period. Hence, we need more frequent sampling to obtain the data typical of the period and to discuss the relationship between environmental factors and activities of phytoplankton.

In the present study, we estimated daily and weekly changes in activities of carbon and nitrogen uptake in May, July and August in 1986 in Lake Nakanuma. We discussed the effects of environmental factors on the activity changes and the relationship between the activities and physiological states of phytoplankton.

\section{Materials and methods}

The survey was carried out from May 7 to August 25 in 1986 in freshwater Lake $\mathrm{Na}$ kanuma (surface area 1.3 ha, maximum depth $13 \mathrm{~m} ; 35^{\circ} 53^{\prime} \mathrm{N}, 140^{\circ} 09^{\prime} \mathrm{E}$ ). Sampling was done daily from May 12 to 31, from July 15 to 31 and from August 15 to 25, and weekly during the other periods. Water samples were collected with a van Dorn bottle at depths of 1 and $7.5 \mathrm{~m}$ at the center of the lake.

Uptake experiments were carried out by the method of Miyazaki et al. (1985a). $\mathrm{NaH}^{13} \mathrm{CO}_{3}$ (99.0 atom\%) and ${ }^{15} \mathrm{NH}_{4} \mathrm{Cl}$ (99.6 atom\%) were injected into a bottle containing sample water 
at concentrations of $31 \mu \mathrm{g}-\mathrm{at} \mathrm{C} \cdot 1^{-1}$ and $5 \mu \mathrm{g}-$ at $\mathrm{N} \cdot 1^{-1}$, respectively. We prepared light and dark bottles. These bottles were incubated for 24 hours at the depths where water samples were collected. After incubation, biological activities were stopped by formalin (final 0 . $3 \%)$. Sample water was filtered through Whatman $\mathrm{GF} / \mathrm{C}$ filters precombusted at $440^{\circ} \mathrm{C}$ for 3 hours. The filters were washed with distilled water and stored at $-20^{\circ} \mathrm{C}$ until analysis. Ratios of stable isotope were analyzed with a quadrupole mass spectrometer equipped with a combustion furnace (Nichiden Anelva TE-150). Carbon and nitrogen contents in particulate matter were also measured with the quadrupole mass spectrometer.

We used the ${ }^{13} \mathrm{C}$ method instead of the ${ }^{14} \mathrm{C}$ method. Both the methods can be similarly used for measurements of photosynthesis in limnological studies, if carbon concentration does not limit photosynthetic activities (MiYAzAKI et al., 1985a).

Neutral sugars were measured as follows. The samples on Whatman GF/C filters were hydrolyzed with $2 \mathrm{ml}$ of $2.5 \mathrm{~N}$ trifluoroacetic acid at $100^{\circ} \mathrm{C}$ for 7 hours (ARAKAWA et al., 1976). After hydrolysis, $50 \mu \mathrm{g} \mathrm{C}$ of deoxyglucose was added as the internal standard. The hydrolysates were centrifuged at $1500 \times g$ for 5 min. The supernatants were evaporated, washed with water and evaporated again to eliminate trifluoroacetic acid. Then, sugars were converted into sugar alcohol with $1 \%$ sodium borohydride at room temperature for 1 hour. Excess sodium borohydride was destroyed by the addition of a few drops of glacial acetic acid. The solution was dried, and $0.5 \%$ methanolic hydrogen chloride was added to the residue. The solution was again evaporated. The procedure was repeated five times. The dry residue was acetylated in $0.5 \mathrm{ml}$ of pyridine and $0.5 \mathrm{ml}$ of acetic anhydride at $100^{\circ} \mathrm{C}$ for 1 hour. Water was then added to the solution. Acetylated sugars were extracted with chloroform, and washed with water three times. Chloroform and residual water were evaporated. The residue was dissolved in chloroform. The acetylated sugars were separated with a
Shimadzu gas chromatograph GC-6A equipped with a flame ionization detector. We used a glass column $(2.5 \mathrm{~mm} \phi \times 2 \mathrm{~m})$ containing $3 \%$ ECNSS on Shimalite (AW-DMCS, 60 80 mesh) $(0.5 \mathrm{~m})$ and $2 \%$ EGSS-X on Chromosorb W (NAW, 80 100 mesh) $(1.5 \mathrm{~m})$ in series. The column was operated at $198^{\circ} \mathrm{C}$ with a temperature of $250^{\circ} \mathrm{C}$ of the injection port and the detector. The carrier gas was nitrogen with a flow rate of $33 \mathrm{ml} \cdot \mathrm{min}^{-1}$.

Chlorophyll $a$ was measured by the method of JefrRey and Humphrey (1975). Ammonium, nitrate, nitrite and phosphate were determined by the methods of SAGI (1966), MulLin and RILEY (1955), Bendschneider and Robinson (1952) and Murphy and Riley (1962), respectively.

Light energy received daily at the depths of 1 and $7.5 \mathrm{~m}$ was estimated as follows. The vertical extinction coefficient ( $k$ ) was calculated from the Secchi depth (D) by the equation $\mathrm{k}=$ 1.9/D (Кікuchi, 1935 ; Iснiмura, 1956). Solar radiation was measured at the Aerological Observatory at Tateno which is located $18 \mathrm{~km}$ north of the sampling station. From the extinction coefficient and the solar radiation, the light energy at the sampling depths was calculated. Though the solar radiation was not exactly the same as that at the sampling station, the calculated light energy may roughly express the in situ one.

\section{Results}

Figure 1 shows changes in carbon uptake rates at the depth of $1 \mathrm{~m}$ from 7 May to 25 August. Carbon uptake rates in the light at 1 $\mathrm{m}$, in general, increased during the survey period, though the uptake rates varied daily. Dark uptake was almost negligible, compared with the light uptake. The light uptake rates at $7.5 \mathrm{~m}$ were between 2.8 and $27 \%$ of those at $1 \mathrm{~m}$.

Figure 2 shows the ammonium uptake rates at the dephts of 1 and $7.5 \mathrm{~m}$ from May 7 to August 25. The uptake rates in the light at $1 \mathrm{~m}$ also increased during the survey period, though day-to-day variations were observed. Dark uptake rates ranged between $29 \sim 70 \%$ of the light uptake. The dark uptake rates increased 
during the survey period from May to August. The light and dark uptake rates at $7.5 \mathrm{~m}$ also increased during the period. The uptake rates in the light at $7.5 \mathrm{~m}$ were between $9 \sim 49 \%$ of those at $1 \mathrm{~m}$. This percentage was larger than that of carbon uptake. The difference between

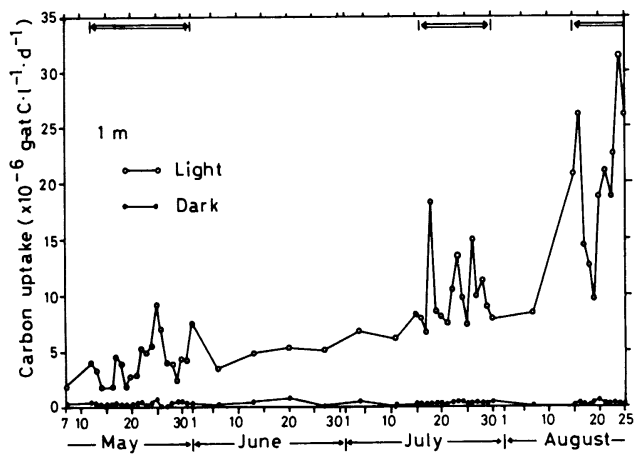

Fig. 1. Carbon uptake rates at the depth of $1 \mathrm{~m}$ in Lake Nakanuma from 7 May to 25 August in 1986. $\Longleftrightarrow$ expresses the periods during which daily sampling was done.

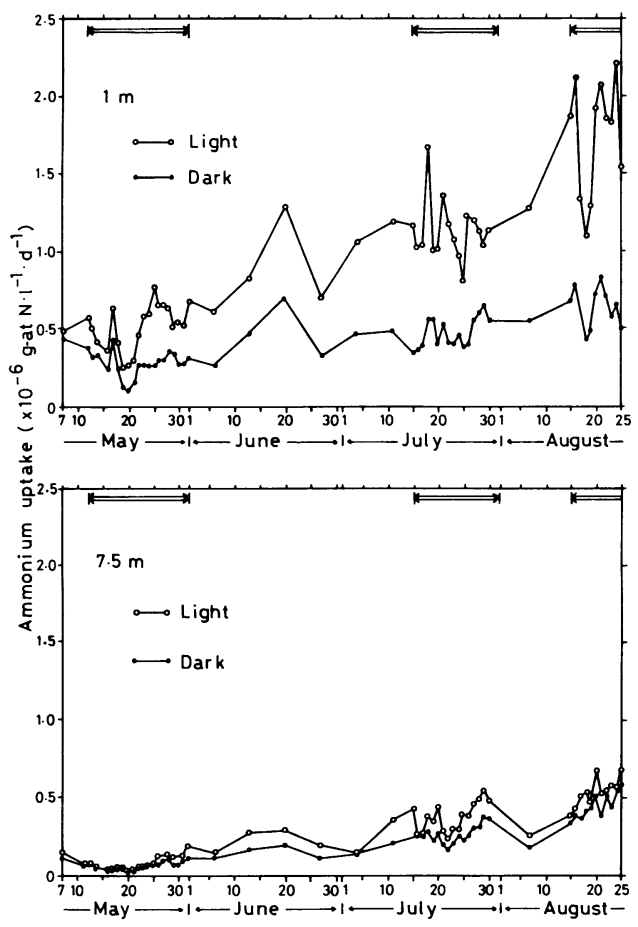

Fig. 2. Ammonium uptake rates at the depths of 1 and $7.5 \mathrm{~m}$ in Lake Nakanuma from 7 May to 25 August in 1986. $\Longleftrightarrow$ expresses the daily sampling periods. the light and dark uptake at $7.5 \mathrm{~m}$ was smaller than that at $1 \mathrm{~m}$.

The changes in chlorophyll $a$ concentrations did not correspond to those in carbon and ammonium uptake rates (Fig. 3). This indicates that the increases of the uptake rates were not necessarily due to the increase of phytoplankton biomass. Chlorophyll $a$ ranged between 0.4 and $6.5 \mu \mathrm{g} \cdot 1^{-1}$ at $1 \mathrm{~m}$ and between 0.9 and $9.1 \mu \mathrm{g} \cdot 1^{-1}$ at $7.5 \mathrm{~m}$.

Water temperature gradually increased from $18^{\circ} \mathrm{C}$ in May to $29^{\circ} \mathrm{C}$ in August at $1 \mathrm{~m}$, and from $10^{\circ} \mathrm{C}$ in May to $18^{\circ} \mathrm{C}$ in August at $7.5 \mathrm{~m}$ (Fig. 4). These increases seem to correspond to the increases in carbon and ammonium uptake.

We examined the relationship between water temperature and the uptake activities (Fig. 5 and 6). Chlorophyll $a$-specific carbon uptake

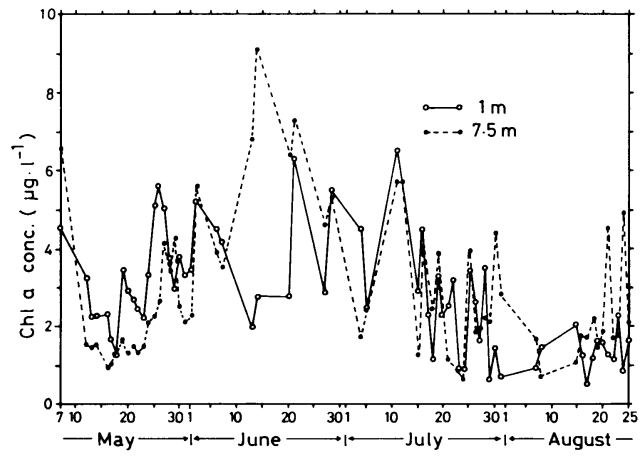

Fig. 3. Changes in chlorophyll $a$ concentration at the depths of 1 and $7.5 \mathrm{~m}$ in Lake $\mathrm{Na}$ kanuma from 7 May to 25 August in 1986.

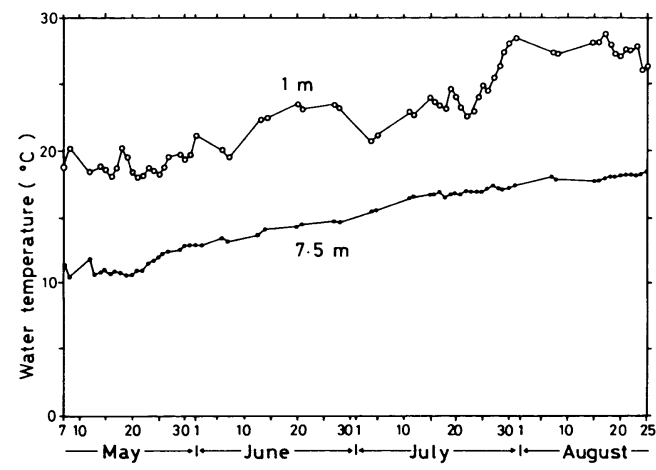

Fig. 4. Water temperature at the depths of 1 and $7.5 \mathrm{~m}$ in Lake Nakanuma from 7 May to 25 August in 1986. 


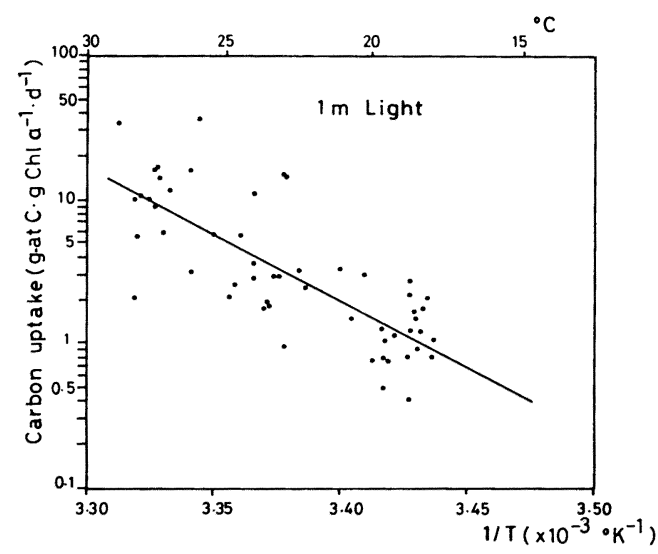

Fig. 5. Relationship between water temperature and chlorophyll $a$ - specific carbon uptake rate. Regression equation : $\log _{10}$ (uptake rate $)=-9226 / \mathrm{T}+31.68\left(r^{2}=0.604\right)$. rates in the light at $1 \mathrm{~m}$, and chlorophyll a specific ammonium uptake rates in the light and dark at 1 and $7.5 \mathrm{~m}$, significantly fitted the Arrhenius-type regression, although we used chlorophyll $a$ - specific rates instead of rate constants. These results suggest that the increased carbon and ammonium uptake during the survey period was due to the increase in water temperature.

We also examined the effect of light. Figure 7 shows changes of light energy received daily at the depths of 1 and $7.5 \mathrm{~m}$. The light energy, on the average, did not increase during the survey period; in fact, it slightly decreased. Thus, light did not show a significant relationship to the activities of carbon and ammonium
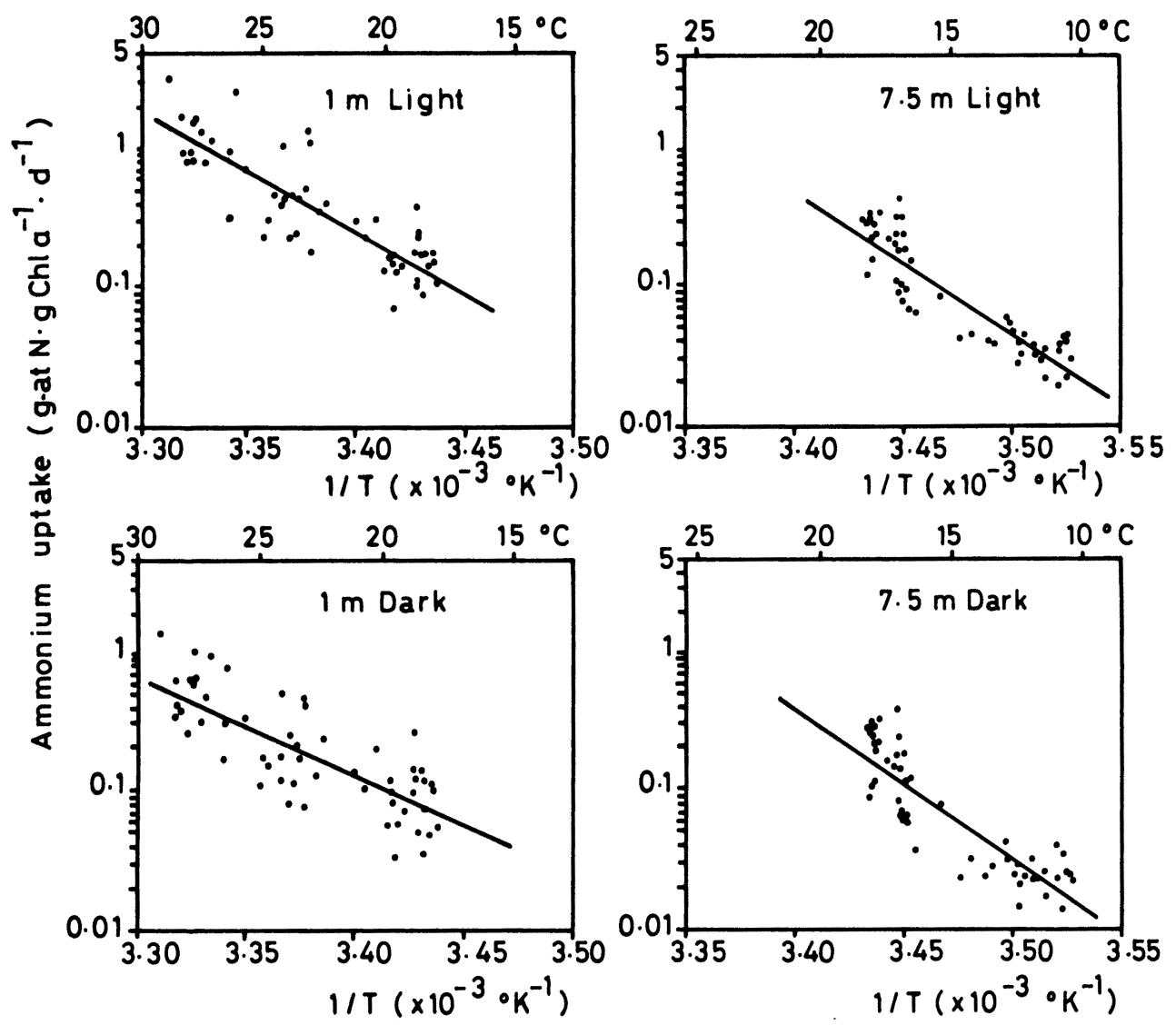

Fig. 6. Relationship between water temperature and chlorophyll $a$-specific ammonium uptake rate. Regression equation : $1 \mathrm{~m}$ Light, $\log _{10}$ (uptake rate) $=-8603 / \mathrm{T}+28.67\left(r^{2}=0.714\right)$ ; $1 \mathrm{~m} \mathrm{Dark}, \log _{10}$ (uptake rate) $=-7249 / \mathrm{T}+23.75\left(r^{2}=0.604\right) ; 7.5 \mathrm{~m} \mathrm{Light,} \log _{10}$ (uptake rate $)=-10671 / \mathrm{T}+36.02\left(r^{2}=0.768\right) ; 7.5 \mathrm{~m} \mathrm{Dark}, \log _{10}($ uptake rate $)=-10672 / \mathrm{T}+36.02$ $\left(r^{2}=0.768\right)$. 


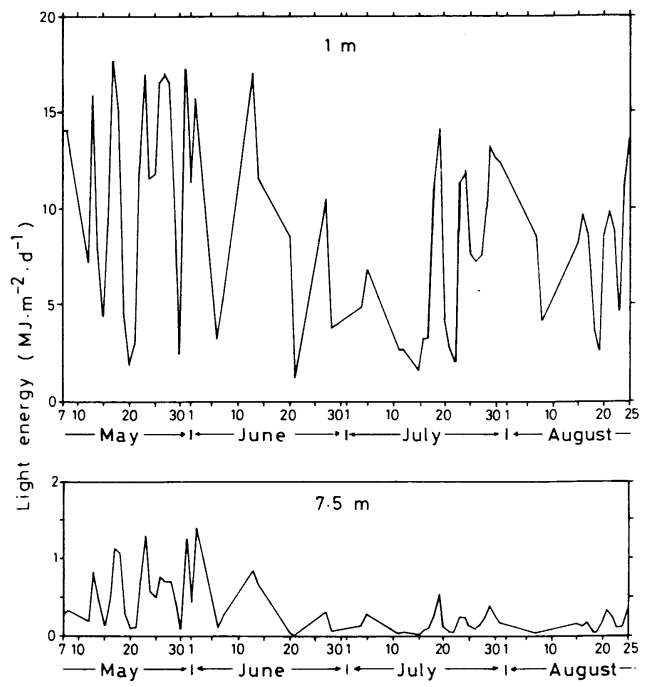

Fig. 7. Light energy received daily at the depths of 1 and $7.5 \mathrm{~m}$ in Lake Nakanuma from 7 May to 25 August in 1986. uptake $\left(0.003 \leqq r^{2} \leqq 0.05\right)$.

Table 1 summarizes concentrations of inorganic nitrogen, inorganic carbon and phosphate in the daily sampling periods. Inorganic nitrogen and carbon were abundant, and thus probably did not limit the uptake activities of phytoplankton (MiYAzAKı et al., 1985a). Phosphate might limit the uptake activities sometimes during the survey period, according to the comparison of the ratios of nutrients with the so- $^{-}$called Redfeled ratio $(\mathrm{C}: \mathrm{N}: \mathrm{P}=106: 16: 1$ (atomic ratio)) (Redfield, 1934). The trends in the ratios of nutrients, however, did not correspond to those in the uptake activities in May to August. This suggests that nutrient conditions were not a major factor contributing to the changes in the uptake activities.

Table 2 shows average values of chlorophyll $a$ - specific carbon uptake rate, chlorophyll $a-$ specific ammonium uptake rate, $\mathrm{C}: \mathrm{N}$ uptake ratio, $\mathrm{C}: \mathrm{N}$ ratio of particulate matter, dark-to light uptake ratio of ammonium, and neutral

Table 1. Average values of inorganic nutrients and chlorophyll $a$, and the ratios of the average values in the periods during which daily sampling was done in Lake Nakanuma. Average values were expressed as "mean \pm standard deviation".

\begin{tabular}{|c|c|c|c|}
\hline & 12 31 May & $15 \sim 30$ July & $15 \sim 25$ August \\
\hline \multicolumn{4}{|l|}{$1 \mathrm{~m}$} \\
\hline $\mathrm{NH}_{4}^{+}\left(\mu \mathrm{g}-\right.$ at $\left.\mathrm{N} \cdot 1^{-1}\right)$ & $8.4 \pm 3.2$ & $3.1 \pm 1.5$ & $3.1 \pm 1.2$ \\
\hline $\mathrm{NO}_{3}^{-}\left(\mu \mathrm{g}-\right.$ at $\left.\mathrm{N} \cdot 1^{-1}\right)$ & $43.2 \pm 14.1$ & $28.6 \pm 4.4$ & $3.0 \pm 2.0$ \\
\hline $\mathrm{NO}_{2}^{-}\left(\mu \mathrm{g}-\right.$ at $\left.\mathrm{N} \cdot 1^{-1}\right)$ & $5.9 \pm 0.7$ & $2.4 \pm 0.4$ & $13.1 \pm 5.4$ \\
\hline $\mathrm{PO}_{4}{ }^{3-}\left(\mu \mathrm{g}-\right.$ at $\left.\mathrm{P} \cdot 1^{-1}\right)$ & $0.4 \pm 0.2$ & $0.2 \pm 0.2$ & $0.1 \pm 0.1$ \\
\hline total $\mathrm{CO}_{2}\left(\mathrm{mg} \mathrm{C} \cdot 1^{-1}\right)$ & $9.3 \pm 0.5$ & $8.4 \pm 0.3$ & $7.6 \pm 0.5$ \\
\hline Chl $a\left(\mu \mathrm{g} \cdot 1^{-1}\right)$ & $3.1 \pm 1.2$ & $2.3 \pm 1.1$ & $1.4 \pm 0.5$ \\
\hline $\begin{array}{l}\text { inorganic } \mathrm{N} / \mathrm{PO}_{4}{ }^{3}-\mathrm{P} \\
\text { (atomic ratio) }\end{array}$ & 161 & 191 & 167 \\
\hline $\begin{array}{l}\mathrm{NH}_{4}{ }^{+}-\mathrm{N} / \mathrm{PO}_{4}{ }^{3-}-\mathrm{P} \\
\text { (atomic ratio) }\end{array}$ & 24 & 18 & 27 \\
\hline \multicolumn{4}{|l|}{$7.5 \mathrm{~m}$} \\
\hline $\mathrm{NH}_{4}^{+}\left(\mu \mathrm{g}-\right.$ at $\left.\mathrm{N} \cdot 1^{-1}\right)$ & $7.5 \pm 0.8$ & $15.6 \pm 1.6$ & $14.7 \pm 1.7$ \\
\hline $\mathrm{NO}_{3}^{-}\left(\mu \mathrm{g}-\right.$ at $\left.\mathrm{N} \cdot 1^{-1}\right)$ & $21.9 \pm 4.5$ & $16.1 \pm 3.3$ & $3.3 \pm 6.2$ \\
\hline $\mathrm{NO}_{2}^{-}\left(\mu \mathrm{g}-\right.$ at $\left.\mathrm{N} \cdot 1^{-1}\right)$ & $2.3 \pm 0.8$ & $8.6 \pm 2.2$ & $11.7 \pm 4.6$ \\
\hline $\mathrm{PO}_{4}{ }^{3-}\left(\mu \mathrm{g}-\right.$ at $\left.\mathrm{P} \cdot 1^{-1}\right)$ & $0.3 \pm 0.1$ & $0.3 \pm 0.3$ & $0.1 \pm 0.1$ \\
\hline total $\mathrm{CO}_{2}\left(\mathrm{mg} \mathrm{C} \cdot 1^{-1}\right)$ & $11.6 \pm 0.5$ & $11.9 \pm 1.0$ & $13.1 \pm 0.3$ \\
\hline Chl $a\left(\mu \mathrm{g} \cdot 1^{-1}\right)$ & $2.0 \pm 1.0$ & $2.4 \pm 1.2$ & $2.3 \pm 1.2$ \\
\hline $\begin{array}{l}\text { inorganic } \mathrm{N} / \mathrm{PO}_{4}{ }^{3-}-\mathrm{P} \\
\text { (atomic ratio) }\end{array}$ & 101 & 120 & 218 \\
\hline $\begin{array}{l}\mathrm{NH}_{4}{ }^{+}-\mathrm{N} / \mathrm{PO}_{4}{ }^{3-}-\mathrm{P} \\
\text { (atomic ratio) }\end{array}$ & 24 & 47 & 108 \\
\hline
\end{tabular}


Table 2. Average values of chlorophyll $a$ - specific rates of carbon and ammonium uptake, $\mathrm{C}: \mathrm{N}$ uptake ratio, $\mathrm{C}: \mathrm{N}$ ratio of particulate matter, dark-to-light uptake ratio of ammonium, and neutral sugars at $1 \mathrm{~m}$ in the periods during which daily sampling was done in Lake Nakanuma, Japan. Data were expressed as "mean \pm standard deviation".

\begin{tabular}{|c|c|c|c|}
\hline & $12 \sim 31$ May & 15 30 July & 15 25 August \\
\hline $\begin{array}{l}\text { carbon uptake } \\
\left(\mathrm{g}-\text { at } \mathrm{C} \cdot \mathrm{g} \mathrm{Chl} a^{-1} \cdot \mathrm{d}^{-1}\right)\end{array}$ & $1.41 \pm 0.70$ & $6.14 \pm 4.89$ & $15.8 \pm 11.2$ \\
\hline $\begin{array}{l}\text { ammonium uptake (light) } \\
\left(\times 10^{-1} \mathrm{~g} \text {-at } \mathrm{N} \cdot \mathrm{g} \mathrm{Chl} a^{-1} \cdot \mathrm{d}^{-1}\right)\end{array}$ & $1.79 \pm 0.76$ & $6.65 \pm 4.45$ & $15.1 \pm 8.0$ \\
\hline $\begin{array}{l}\text { ammonium uptake }(\text { dark }) \\
\left(\times 10^{-1} \mathrm{~g} \text {-at } \mathrm{N} \cdot \mathrm{g} \mathrm{Chl} a^{-1} \cdot \mathrm{d}^{-1}\right)\end{array}$ & $1.02 \pm 0.56$ & $2.92 \pm 2.45$ & $5.63 \pm 3.24$ \\
\hline $\begin{array}{l}\mathrm{C}: \mathrm{N} \text { uptake ratio (light) } \\
\text { (atomic ratio) }\end{array}$ & $8.0 \pm 2.3$ & $8.8 \pm 1.0$ & $11.5 \pm 2.5$ \\
\hline $\begin{array}{l}\mathrm{C}: \mathrm{N} \text { ratio of particulate matter } \\
\text { (atomic ratio) }\end{array}$ & $7.1 \pm 0.7$ & $7.2 \pm 0.9$ & $7.9 \pm 0.4$ \\
\hline $\begin{array}{l}\mathrm{NH}_{4}{ }^{+} \text {uptake (dark)/(light) } \\
(\%)\end{array}$ & $56.6 \pm 13.9$ & $42.5 \pm 9.4$ & $37.1 \pm 4.4$ \\
\hline neutral sugars $\left(\mu \mathrm{g} \mathrm{C} \cdot 1^{-1}\right)$ & $81 \pm 24$ & $116 \pm 23$ & \pm 21 \\
\hline
\end{tabular}

sugars at $1 \mathrm{~m}$ in the daily sampling periods. The chlorophyll $a$ - specific carbon and ammonium uptake rates increased as the season progressed. This, along with the small change of chlorophyll a (Table 1), suggests that loss of carbon and nitrogen taken up into phytoplankton cells increased as the season progressed. The relatively small change of neutral sugars, compared with the uptake rates, may support this suggestion, because neutral sugars are components of the cell wall, stored materials etc. of phytoplankton cells.

$\mathrm{C}: \mathrm{N}$ uptake ratios and $\mathrm{C}: \mathrm{N}$ ratios of particulate matter at $1 \mathrm{~m}$ did not change as much as the uptake rates. The relatively constant $\mathrm{C}: \mathrm{N}$ uptake ratios and $\mathrm{C}: \mathrm{N}$ ratios suggest that the changes in the $\mathrm{C}: \mathrm{N}$ ratio of loss rates of carbon and nitrogen might be relatively small, compared with the changes in the loss rates themselves, though the $\mathrm{C}: \mathrm{N}$ ratio of such rates might slightly increase later in the season due to a slight increase in the $\mathrm{C}: \mathrm{N}$ uptake ratio and the constancy of the $\mathrm{C}: \mathrm{N}$ ratio.

The dark-to-light uptake ratio of ammonium at $1 \mathrm{~m}$ slightly decreased as the season progressed. This suggests that the activities of uptake of ammonium at $1 \mathrm{~m}$ in July and August became more light-dependent and probably more dependent on stored materials such as carbohydrates than in May (MiyAzAKı et al., 1987).

Table 3 exhibits the average values at $7.5 \mathrm{~m}$. Though carbon uptake rates at $7.5 \mathrm{~m}$ were much smaller than those at $1 \mathrm{~m}$, ammonium uptake rates were fairly large. In fact, $\mathrm{C}: \mathrm{N}$ uptake ratios were smaller than those at $1 \mathrm{~m}$. These ammonium uptake rates at $7.5 \mathrm{~m}$ may be in part due to the smaller dependency of the uptake on light and the larger dependency of ammonium uptake on stored material at this depth (Miyazaki et al., 1987). This may be supported by the larger dark-to-light ratios of ammonium uptake at $7.5 \mathrm{~m}$ than those at $1 \mathrm{~m}$. The decrease of the $\mathrm{C}: \mathrm{N}$ uptake ratio, the increase of the dark-to-light ammonium uptake ratio and the increase of neutral sugars as the season progressed suggest that ammonium uptake at $7.5 \mathrm{~m}$ later in summer was more dependent on stored materials than in May.

\section{Discussion}

The incubation time of one day in the present study may cause non-linear time courses of uptake (Goldman et al., 1981 ; Harrison, 1983) and may affect the uptake activities. Respiration, excretion and grazing in the incubation bottles may also affect them. However, the uptake activities obtained in the present study 
Table 3. Average values of chlorophyll $a$-specific rates of carbon and ammonium uptake, C: N uptake ratio, $\mathrm{C}: \mathrm{N}$ ratio of particulate matter, dark-to-light uptake ratio of ammonium, and neutral sugars at $7.5 \mathrm{~m}$ in the periods during which daily sampling was done in Lake Nakanuma, Japan. Date were expressed as "mean \pm standanrd deviation".

\begin{tabular}{|c|c|c|c|}
\hline & 12 31 May & $15 \sim 30$ July & 15 25 August \\
\hline $\begin{array}{l}\text { carbon uptake } \\
\left(\mathrm{g}-\text { at } \mathrm{C} \cdot \mathrm{g} \mathrm{Chl} a^{-1} \cdot \mathrm{d}^{-1}\right)\end{array}$ & $0.18 \pm 0.11$ & $0.53 \pm 0.31$ & $0.59 \pm 0.19$ \\
\hline $\begin{array}{l}\text { ammonium uptake (light) } \\
\left(\times 10^{-1} \mathrm{~g} \text {-at } \mathrm{N} \cdot \mathrm{g} \text { Chl } a^{-1} \cdot \mathrm{d}^{-1}\right)\end{array}$ & $0.36 \pm 0.10$ & $2.03 \pm 1.16$ & $2.80 \pm 0.90$ \\
\hline $\begin{array}{l}\text { ammonium uptake }(\text { dark }) \\
\left(\times 10^{-1} \mathrm{~g} \text {-at } \mathrm{N} \cdot \mathrm{g} \mathrm{Chl} a^{-1} \cdot \mathrm{d}^{-1}\right)\end{array}$ & $0.25 \pm 0.08$ & $1.39 \pm 0.91$ & $2.23 \pm 0.83$ \\
\hline $\begin{array}{l}\mathrm{C}: \mathrm{N} \text { uptake ratio (light) } \\
\text { (atomic ratio) }\end{array}$ & $5.6 \pm 2.9$ & $2.6 \pm 0.8$ & $2.2 \pm 0.4$ \\
\hline $\begin{array}{l}\mathrm{C}: \mathrm{N} \text { ratio of particulate matter } \\
\text { (atomic ratio) }\end{array}$ & $7.6 \pm 0.7$ & $7.1 \pm 1.2$ & $7.2 \pm 0.2$ \\
\hline $\begin{array}{l}\mathrm{NH}_{4}{ }^{+} \text {uptake }(\text { dark }) /(\text { light }) \\
(\%)\end{array}$ & $67.0 \pm 19.0$ & $72.2 \pm 11.5$ & $83.3 \pm 8.3$ \\
\hline neutral sugars $\left(\mu \mathrm{g} \mathrm{C} \cdot 1^{-1}\right)$ & $40 \pm 15$ & $117 \pm 65$ & \pm 19 \\
\hline
\end{tabular}

serve as a first approximation of uptake values, and thus may be sufficient to examine the effects of environmental factors discussed in the present study.

The daily sampling showed considerable, day- to-day variations in the uptake activities (Figs. 1 and 2). The uptake rates sometimes exhibited similar values in May, July and August. If sampling intervals were longer and uptake values happened to be similar, it would be difficult to find the trends in the activity changes, that is, higher uptake activities in later summer.

The results indicate that the increases in uptake activities in summer were mostly due to the increase in water temperature (Fig. 5). Other factors such as light and nutrient conditions had little influence in terms of these activities (Fig. 7 and Table 1). Dissolved oxygen also does not seem to correlate with the uptake activities. Dissolved oxygen was relatively constant $\left(8 \sim 11 \mathrm{mg} \mathrm{O}_{2} \cdot 1^{-1}\right)$ at $1 \mathrm{~m}$ from April to August in 1984 in Lake Nakanuma (unpublished). This change would not correspond to that in uptake activities.

Light energy received at $1 \mathrm{~m}$ during the survey period might saturate the photosynthesis, because the intensitiy of the light energy at $1 \mathrm{~m}$ was mostly higher than that at which most photosynthesis levels off. The saturated photosynthesis $\left(\mathrm{P}_{\max }\right)$ is temperature-dependent (Aruga, 1965). Thus, there may be some correlation between carbon uptake at $1 \mathrm{~m}$ and water temperature.

The temperature-dependency of ammonium uptake activities in the light at $1 \mathrm{~m}$ might be observed, because the uptake activities represented the light-saturated portion of ammonium uptake, like $\mathrm{P}_{\max }$ in carbon uptake at $1 \mathrm{~m}$ (e.g., MacIsaac and Dugdale, 1972). On the other hand, the change of uptake activities in the dark at $1 \mathrm{~m}$ might originate from the dependence of dark uptake reactions on temperature. Ammonium uptake activities at $7.5 \mathrm{~m}$ might become similarly dependent on water temperature, because light at this depth was similar to or less than $1 \%$ of surface irradiance (Fig. 6). The $Q_{10}$ values $(6.6 \sim 17)$, which were roughly estimated from the increase of uptake activities between $15^{\circ} \mathrm{C}$ and $25^{\circ} \mathrm{C}$, were much larger than $\mathrm{Q}_{10}$ values of most other biochemical reactions. The regression of temperature $v s$ uptake rates in this study is roughly converted to the exponential temperature dependency (KeLLER, 1989) by using an approximation of power series expansion. This is evident in Figures 5 and 6 , where the upper abscissas show water temperature in degrees centigrade and it is 
almost linearly spaced. Then, $\mathrm{Q}_{10}$ values were estimated from the relationships between uptake activities and temperature. The appearance of the higher $Q_{10}$ values may be partly because the data in the present study were obtained from mixed populations of phytoplankton. Well adapted algal species which had different, probably higher uptake activities than less adapted species might dominate the uptake. Furthermore, well adapted algal species might successively change as the season progressed. Then. The larger $\mathrm{Q}_{10}$ values might appear.

Though the temperature dependency of uptake activities was observed during the entire survey period (more than 3 months), it was not observed in the daily sampling periods (2 weeks). Temperature changes were small in the shorter periods, so the dependency was not observed. The activity changes in the daily sampling periods may be due to differences in growth phase and loss of algae (MIYAZAKI et al., 1989).

Though uptake activities increased in summer (Fig. 1 and 2), biomass did not increase as much, as indicated by the change of chlorophyll $a$ (Tables 2 and 3, Fig. 3). A possible explanation is that carbon and nitrogen taken up into phytoplankton cells may be lost through processes such as excretion (WATANABE, 1980), respiration (RAVEN and BEARDALL, 1981). Increases of water temperature may increase the rates of many metabolic reactions. If some nutrients limit the growth of phytoplankton, other nutrients which may be more taken up into cells at higher temperature may not be used for the build-up of cells (Hama et al., 1988). Then, incorporated nutrients such as inorganic carbon and nitrogen which do not limit phytoplankton growth may be lost through excretion, respiration etc.

Other loss processes may be involved in the small biomass change, though we cannot infer the extent of loss from the present data. Grazing by zooplankton and sedimentation may be examples of the loss processes (JEwson et al., 1981 ; Reynolds, 1982 ; Pedrós-Alıó et al., 1987).

\section{Acknowledgments}

The authors would like to express their gratitude to Prof. H. Iwaki for his encouragement during the work. They also thank the Aerological Observatory for permitting the use of the data on solar radiation.

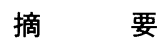

\section{5月から 8 月にかけての中沼における炭素・ アンモニア取込みの変化と水温との関係}

1986 年 5 月から 8 月にかけて毎日あるいは毎週, 竜ケ崎市の中沼において無機炭素およびアンモニ ア取込活性を測定し，環境要因との関係を考察し た。こまかな変動は観察されたが，平均すると， 5 月から 8 月にかけて, 明条件下 $1 \mathrm{~m}$ 層での炭素 取込活性は 1.4 から $15.8\left(\mathrm{~g}-\mathrm{at} \mathrm{C} \cdot \mathrm{g} \mathrm{Chl} a^{-1} \cdot \mathrm{d}^{-1}\right)$ へ, アンモニア取込活性は 1.8 から $15.1\left(\times 10^{-1}\right.$ $\mathrm{g}$-at $\left.\mathrm{N} \cdot \mathrm{g} \mathrm{Chl} a^{-1} \cdot \mathrm{d}^{-1}\right)$ へ上昇した。水温が, こ の活性上昇に最も大きく影響していた。光および 栄養塩条件の影響は, 水温にくらべると少なかっ た。クロロフィル $a$ 濃度は 0.4 から $9.1\left(\mu \mathrm{g} \cdot 1^{-1}\right)$ の間にあり, 取込活性の変化とは対応していなか った。中沼における炭素・窒素取込活性の変化は かならずしも植物プランクトン量の変動とは結び ついていないことを,これらの結果は示している。

\section{References}

Arakawa, Y., T. Imanari, and Z. Tamura (1976): Determination of neutral and amino sugars in glycoproteins by gas chromatography. Chem. Pharm. Bull., 24 : 2032-2037.

ARUGA, Y. (1965) : Ecological studies of photosynthesis and matter production of phytoplankton II. Photosynthesis of algae in relation to light intensity and temperature. Bot. Mag. Tokyo. $78: 360-365$.

BendsChNeider, K., and R. J. Robinson (1952) : A new spectrophotometric method for the determination of nitrite in sea water. J. Mar. Res., $11: 87-96$.

CôtÉ, B., and T. Platt (1983) : Day-to-day variations in the spring - summer photosynthetic parameters of coastal marine phytoplankton. Limnol. Oceanogr., $28: 320-344$.

FALKOWSki, P. G. (1984) : Physiological responses of phytoplankton to light regimes. J. Plankton Res., $6: 295-307$.

Goldman, J. C., C. D. Taylor, and P. M. Glibert 
(1981) : Non-linear time-course uptake of carbon and ammonium by marine phytoplankton. Mar. Ecol. Prog. Ser., 6 : 137-148.

Hama, T., N. Handa, M. Takahashi, F. Whitney, and C. S. Wong (1988) : Change in distribution patterns of photosynthetically incorporated $\mathrm{C}$ during phytoplankton bloom in controlled experimental ecosystem. J. Exp. Mar. Biol. Ecol., $120: 39-56$.

Harrison, W. G. (1983) : The time-course of uptake of inorganic and organic nitrogen compounds by phytoplankton from the Eastern Canadian Arctic: A comparison with temperate and tropical populations. Limnol. Oceanogr., $28: 1231-1237$.

IcHimurA, S. (1956) : On the ecological meaning of transparency for the production of matter in phytoplankton community of lake. Bot. Mag. Tokyo, $69: 219-226$.

Jefrerey, S. W., and G. F. Humphrey, (1975) : New spectrophotometric equations for determining chlorophylls $a, b, c_{1}$ and $c_{2}$ in higher plant, algae and natural phytoplankton. Biochem. Physiol. Pflanzen, 167 : 192-194.

Jewson, D. H., B. H. Rippley, and W. K. Gilmore (1981) : Loss rates from sedimentation, parasitism, and grazing during the growth, nutrient limitation, and dormancy of a diatom crop. Limnol. Oceanogr., 26 : 1045-1056.

Keller, A. A. (1989) : Modeling the effects of temperature, light, and nutrients on primary productivity : An empirical and a mechanistic approach compared. Limnol. Oceanogr., 34 : $82-95$.

Kikuchi, K. (1935): The relation between the under-water illumination and the transparency of the water of lakes. Jpn. J. Limnol., 5 : 121124 (in Japanese)

KIRK, J. T. O. (1983) : Light and photosynthesis in aquatic ecosystems. 401pp. Canbridge University Press, Cambridge.

MacisaAC, J. J., and Dugdale, R. C. (1972) : Interactions of light and inorganic nitrogen in controlling nitrogen uptake in the sea. Deep-Sea Res., 19 : 209-232.

Miyazaki, T., Y. Honjo, and S. IChimura (1985a): Applicablity of the stable isotope methods using ${ }^{13} \mathrm{C}$ and ${ }^{15} \mathrm{~N}$ simultaneously to the estimation of carbon and nitrogen assimilation in a eutrophic, freshwater lake, Lake Nakanuma, Japan. Arch. Hydrobiol., 102 : 355-365.

MiyAzAKI, T., Y. Honjo, and S. Ichimura (1985b) : Uptake of carbon and inorganic nitrogen in a eutrophic lake, Lake Nakanuma, Japan, from spring through summer. Arch. Hydrobiol., $102: 473-485$.

Miyazaki, T., H. Suyama, and H. Uotani (1987) : Diel changes of uptake of inorganic carbon and nitrogen by phytoplankton, and the relationship between inorganic carbon and nitrogen uptake in Lake Nakanuma, Japan. J. Plankton Res., 9 : 513-524.

Miyazaki, T., M. Watase, and K. Miyake (1989) : Daily changes of inorganic carbon and nitrogen, and their relation to phytoplankton blooms in late-early summer in Lake $\mathrm{Na}$ kanuma, Japan. Hydrobiologia, in press.

Mullin, J. B., and J. P. Riley (1955) : The spectrophotometric determination of nitrate in natural waters, with particular reference to sea water. Anal. Chim. Acta, 12 : 464-480.

Murphy, J., and J. P. Riley (1962) : A modified single solution method for the determination of phosphate in natural waters. Anal. Chim. Acta, $27: 31-36$.

Pedrós-Alió, C. P., J. M. Gasol, and R. Glerrero (1987) : On the ecology of a Cryptomonas phaseolus population forming a metalimnetic bloom in Lake Ciso, Spain: Annual distribution and loss factors. Limnol. Oceanogr., 32 : 285298.

RAIEN. J. A., and J. BeARdall (1981) : Respiration and photorespiration. Physiological Bases of Phytoplankton Ecology. Can. Bull. Fish. Aquat. Sci., 210 (ed. PlatT, T. ) : 55-82.

Redfielis, A. C. (1934) : On the proportions of organic derivatives in sea water and their relation to the composition of plankton. James Johnstone Memorial Volume, 176-192. Liverpool University press, Liverpool (cited in "Moss, B. (1988) : Ecology of Fresh Waters. Man and Medium. Second edition. BLACKWEll, Oxford").

REynolds, C. S. (1982) : The sedimentary flux of phytoplankton in the south basin of Windermere. Limnol. Oceanogr., 27 : 1162-1175.

ROBARTS, R. D. (1984) : Factors controlling primary production in hypereutrophic lake (Hartoeespoort Dam. South Africa). J. Plankton Res., 6 : 91-105.

SAGi, T. (1966) : Determination of ammonia in sea water by the indophenol method and its application to coastal and off-shore waters. Oceanorgr. Mag., $18:$ 43-51.

Seike, Y., K. Kondo, Y. DAte, and Y. Ishida (1986) : Nitrogen metabolism in the brackish Lake 
Nakanoumi. I. Uptake rate of inorganic nitrogen by phytoplankton. Jpn. J. Limnol., 47 : 133-141 (in Japanese).

Tilzer, M. M. (1984) : Estimation of phytoplankton loss rates from daily photosynthetic rates and observed biomass changes in Lake Constance. J. Plankton Res., 6 : 309-324.

WatAnABE, Y. (1980) : A study of the excretion and extracellular products of natural phytoplankton in Lake Nakanuma, Japan. Int. Revue ges. Hydrobiol., 65 : 809-834.

Yamaguchi, Y., and S. Ichimura (1972) : Dynamic status of primary production in Lake Yunoko, a small eutrophic subalpine lake in central Japan. Bot. Mag. Tokyo, 85 : 157-176.

(著者: 宮崎龍雄・渡瀬正憲 -三宅一義, 筑波大学生 物科学系, 干 305 茨城県つくば市天王台 1-1-1; Tatsuo Miyazaki, Masanori Watase and Kazuyoshi MiYAKE, Institute of Biological Sciences, University of Tsukuba, Tsukuba-shi, Ibaraki, 305)

Received : 27 March 1989

Accepted : 21 July 1989 